\title{
Assessment of Knowledge of Kenya's Breast Milk Substitutes Act (2012) among Nurses in Mbagathi and Pumwani Hospital, Kenya
}

\author{
Nyaboke, Clement ${ }^{1}$, Gesimba, Beatrice ${ }^{2}$, Juma, Rose $^{3}$ \\ ${ }^{1,2,3}$ Department of Public Health and Human Dietetics, Kenya Methodist University
}

Corresponding Author: Nyaboke, Clement

\begin{abstract}
Breast Milk Substitutes Regulation and Control Act, 2012 aimed to provide for appropriate marketing and distribution of breast milk substitutes, safe and adequate nutrition for infants, through the promotion of breast-feeding and proper use of breast milk substitutes. Nurses are responsible for providing information about benefits of breastfeeding to help the new mother to make a fully informed decision about infant nutrition. The aim of this study was to determine nurses' knowledge on the recommendations of the BMS Act in Mbagathi and Pumwani Hospitals, Nairobi County. This study used a cross-sectional descriptive research/study design. The target population were nurses who all work in maternity wards because of their responsibility for counseling mothers on infant nutrition. The study used a sample of 200 nurses. Questionnaires were use to collect data. Data analysis involved descriptive statistics and chi-square Analysis with the help of SPSS. Majority (68\%) of the respondents had high knowledge. There was a significant relationship $(p=0.014)$ between the level of education and nurses knowledge on BMS. Nurse's knowledge on the recommendations of the BMS Act was generally high. Nurses with bachelors and postgraduate degree were more likely to have high knowledge than those with certificates and diplomas in nursing. Diploma curriculum therefore needs to be bolstered to include current recommendations of breastfeeding in line with the BMS Act.
\end{abstract}

Keywords: Breastfeeding, Breast Milk Substitutes Regulation and Control Act, Nurses knowledge

\section{INTRODUCTION}

Milk from Human is considered as nature's best newborn child food from dietary, immunological and sanitation perspectives. [1] In any case, time imperatives, wellbeing conditions and urbanization may cause the early end of breastfeeding. In this manner, there is a need to give an elective method for taking care of for those babies who can't have breasted or taken care of. The suggested diet for babies is human milk. ${ }^{[2]}$ Human milk is also considered best for infants from nutritional and immunological points of view, as well as from the standpoint of protection against harmful bacteria. [1] Nevertheless, time requirements and urbanization may cause the early end of breastfed. A few newborn children are not bosom taken care of because of short flexibly of bosom milk, deficient sustenance and wellbeing states of nursing moms, passing of moms during or after labor, and the need of certain moms working. Subsequently, there is a requirement for an elective method for taking care of for babies who do not have availability or accessibility to human breast milk. ${ }^{[2]}$

As UNICEF ongoing State of the World's Children report shows breastfeeding rates over the locale change - with restrictive breastfeeding rates at 69 percent in Burundi, 62 percent in Uganda, 52 percent in Ethiopia and Tanzania with 50 percent. ${ }^{[3]}$ As indicated by Save the Children's East Africa Regional Director Hussein Halane in August 2, 2013, Rwanda 
is the leading country in EBF of infants on the continent drastically reducing child deaths. Countries like Rwanda where 85 percent of kids are solely breastfed for the initial a half year have indicated achievement is conceivable. ${ }^{[3]}$ In Kenya just 32 percent of youngsters are solely breastfed for the initial a half year implying that an excessive number of kids are passing up essential supplements they need in the primary long periods of life. ${ }^{[4]}$

In 1981, the International Code on Marketing Breast Milk Substitutes was conceived by the WHO, to shield moms and wellbeing laborers from business pressure by bosom milk substitute makers. ${ }^{[5]}$ This was supported by the newborn child recipe producers and prohibits the arrangement of free examples of baby equation to moms, medical attendants and wellbeing offices. In 2004 the World Health Assembly passed an extra goal to guarantee that the act of appropriating unconditional present examples of newborn child recipe through doctors' workplaces and other medicinal services offices was additionally suspended. In 2001, the WHO/UNICEF Baby Friendly Hospital Initiative, a worldwide activity and organized technique for advancing, ensuring, and supporting breastfeeding, was created. ${ }^{[6]}$ The point of this key program was to join the fundamental standards of the International Code, The Ten Steps to Successful Breastfeeding and the Inncocenti Declaration. The code specifies that there ought to be positively no advancement of breastmilk substitutes, containers and nipples to the overall population; that neither wellbeing offices nor wellbeing experts ought to have a job in advancing breastmilk substitutes; and that free examples ought not be given to pregnant ladies, new moms or families. ${ }^{[7]}$

Nurses therefore require knowledge of the International Code to protect, promote and support breastfeeding at the hospital level and in community where they live and thereby, contribute to the global efforts in improving the nutritional star growth and development of infants and young children. Effective infant feeding counselling determinant of breastfeeding. ${ }^{[6]}$ The International Code in effect is a health policy that recommends guidelines for breastfeed promotion, the dissemination of relevant information on infant feeding, recommend appropriate measures to be taken in health care systems, recommends guidelines on marketing of infant formula which is a breast milk substitute at health care facilities, implementation and monitoring. [5] As a health policy recommendation, also a determinant of breastfeeding because it aims to limit or reduce commercial pressure such as advertising and formula promotion in hospitals that threaten mothers' decision exclusively breastfeed. ${ }^{[8]}$ Kenya adopted the code and enacted the BMS Regulation and Control Act in November 2012, therefore adopting recommendations put forward in the code.

Knowledge of recommendations of the International Code for IYC counseling is a professional obligation for all $\mathrm{HCWs}$ to guide the feeding-decision of others and to follow to the recommendations of the International Code, thereby, contribute to improving infant nutrition outcomes. ${ }^{[8]}$ The research problem is based on the lack of evidence about the information and knowledge of the recommendations of the International Code on BMS by health workers in Kenya responsible for counseling mothers of new-born babies on IYC nutrition. Furthermore, no research has been done in Kenya to assess the awareness, attitudes and the practice among the HCWs on the BMS Act of Kenya as stipulated by the WHO and this study addressed this gap despite of the Act being in place. The aim of this study therefore was to determine nurses' knowledge on the recommendations of the BMS Act in Mbagathi and Pumwani Hospitals, Nairobi County.

\section{METHODOLOGY}

This study used a cross-sectional descriptive research/study design which is the study of a phenomenon as it occurs 
naturally in its real life situations. The researcher describes the characteristics of the phenomenon in terms of context, frequency and distribution of the situation, with a focus on measuring the awareness and nurses' level of knowledge of the Code. Selected hospitals there location is within the capital city of Kenya which is Nairobi and are main districts Hospitals serving almost a population of more than 3 million people. The Mbagathi hospital, is for, midwifery, medical, nursing and dental. Mbagathi, which was called Infectious Diseases Hospital" (IDH) originally, and was under Kenyatta National Hospital until 1995. The hospital was build in the 1950's to offer health care services for the infectious diseases, like Tuberculosis, Measles, Meningitis and Leprosy. It has a 200 bed capacity with the following services: Maternity with new born, MRI, Xrays Growth child monitoring and outpatient Services. Pumwani Hospital is a referral maternity hospital located at east part of Nairobi city. It was founded in 1926 by charitable organization. Pumwani is the largest maternity hospital in Kenya and in subs Sahara Africa.

The target population were nurses who all work in maternity wards because of their responsibility for counseling mothers on infant nutrition. According to the hospital records, they are estimated to be 400 nurses in Mbagathi and Pumwani Hospitals, Nairobi County. In this study, Yamane formula was used for the simple random sampling technique method $\mathrm{n}=\mathrm{N} /\left(1+\mathrm{Ne}^{\wedge} 2\right)^{[9]}$

Where

$\mathrm{n}=$ sample size

$\mathrm{N}=$ Population Size

$\mathrm{e}=$ level of precision

At $95 \%$ level of confidence and $\mathrm{p}=5$

$\mathrm{n}=400 /(1+400 * 0.0025)$

$\mathrm{n}=200$

The study used Semi-structured questionnaires because of the element of anonymity as some of the information which was required was sensitive. Questionnaires were more effective to gather more information. Participants from the target population were required to complete the questionnaire. A semistructured questionnaire was to collect data on awareness of the nurses and other health workers on the Code of the BMS. Completeness for the questionnaires was checked. Scrutinizing for questionnaires was done for error checking during editing. SPSS (V. 25.0) was used to analyze quantitative data. The presentation of the data was done through frequency tables and figures. Qualitative data was analyzed using content analysis and grouped according to the themes. Chi Square was used in this study to assess statements significance pertaining KAP on BMS.

\section{RESULTS}

The respondents samples filled-in the form and the questionnaires were returned with a response rate of $93.0 \%$ $(n=186)$.

\section{Socio-Demographic Characteristics of Respondents}

It was determined that majority of the respondents were females who were $83.9 \%$ and on the age bracket, most or majority $100(53.8 \%)$ were between 31-40 years, followed by 58[31.2\%] who were between 20-30 years. It was noted that most were married [111,59.7\%] and the rest cited they were in not in any form of union. It was established majority $(122,65.6 \%)$ had nursing diploma/certificate, followed by those with nursing bachelors degree $[53,28.5 \%]$. Almost all were nurses $[179,96.2 \%]$ and on the experience at the post, $49.5 \%$ cited they have work experience of less than five years while $85[45.7 \%$ ] had work experience between 610 years] and their current duty was in the PNC [69,37.1\%], those at ANC were $35,18.8 \%$ ] while $59[31.7 \%$ ] worked at the pediatric ward. On the numbers of work of the respondents had worked, a third indicated between 6-10 years $(58,31.2 \%)$ while a quarter cited they have been working for more than ten years [47,25.3\%]. 
Nyaboke, Clement et.al. Assessment of knowledge of Kenya's breast milk substitutes act (2012) among nurses in Mbagathi and Pumwani Hospital, Kenya.

It was noted that $43 \%$ they counselled between 6-10 women weekly on infant counselled between 11-15 women on nutrition compared to $59[31.7 \%]$ who weekly basis.

Table 1 Socio-Demographic Characteristics of Respondents

\begin{tabular}{|c|c|c|c|}
\hline & & $\mathrm{n}[\mathbf{1 8 6}]$ & $\%$ \\
\hline \multirow{2}{*}{ Institution } & Mbagathi & 85 & 45.7 \\
\hline & Pumwani & 101 & 54.3 \\
\hline \multirow[t]{2}{*}{ Gender } & Male & 30 & 16.1 \\
\hline & Female & 156 & 83.9 \\
\hline \multirow[t]{4}{*}{ Age (in years) } & Between 20-30 years & 58 & 31.2 \\
\hline & Between $31-40$ years & 100 & 53.8 \\
\hline & Between $41-50$ years & 24 & 12.9 \\
\hline & More than 50 years & 4 & 2.2 \\
\hline \multirow[t]{2}{*}{ Marital status } & Married & 111 & 59.7 \\
\hline & Single & 75 & 40.3 \\
\hline \multirow[t]{3}{*}{ Level of education } & Nursing bachelor's degree & 53 & 28.5 \\
\hline & Nurse with a postgraduate degree & 11 & 5.9 \\
\hline & College [Certificate] & 122 & 65.6 \\
\hline \multirow[t]{2}{*}{ Current Occupation } & Nursing Ward Manager & 7 & 3.8 \\
\hline & Nurse & 179 & 96.2 \\
\hline \multirow[t]{3}{*}{ Number of years } & less than 5 years & 92 & 49.5 \\
\hline & Between 6-10 years & 85 & 45.7 \\
\hline & More than 10 years & 9 & 4.8 \\
\hline \multirow[t]{4}{*}{ Current duty place } & ANC & 35 & 18.8 \\
\hline & Delivery Suite & 23 & 12.4 \\
\hline & $\mathrm{PNC}$ & 69 & 37.1 \\
\hline & Pediatric Ward & 59 & 31.7 \\
\hline \multirow[t]{4}{*}{ Number of years at work } & Less than one year & 44 & 23.7 \\
\hline & Between 1-5 years & 37 & 19.9 \\
\hline & Between 6-10 years & 58 & 31.2 \\
\hline & More than 10 years & 47 & 25.3 \\
\hline \multirow[t]{5}{*}{ Women/mothers counselled weekly } & None & 4 & 2.2 \\
\hline & $1-5$ mother & 42 & 22.6 \\
\hline & 6-10 mother & 80 & 43.0 \\
\hline & 11-15 mother & 59 & 31.7 \\
\hline & More than 15 women & 1 & .5 \\
\hline
\end{tabular}

\section{Nurses' Knowledge on BMS}

Table 2 Nurses' Knowledge on BMS

\begin{tabular}{|c|c|c|c|}
\hline & & $\mathrm{n}[\mathbf{1 8 6 ]}$ & $\%$ \\
\hline \multirow[t]{2}{*}{ Aware of IC on BMS } & Yes & 168 & 90.3 \\
\hline & No & 18 & 9.7 \\
\hline \multirow{4}{*}{$\begin{array}{l}\text { Place learn about recommendations of the International Code of } \\
\text { Marketing Breast-milk substitute }\end{array}$} & At nursing school & 15 & 8.1 \\
\hline & At your place of work & 83 & 44.6 \\
\hline & $\begin{array}{l}\text { Through continuing education programs } \\
\text { while employed at my expense }\end{array}$ & 76 & 40.9 \\
\hline & Nursing journals & 12 & 6.5 \\
\hline \multirow[t]{2}{*}{ International Code say about Marketing Breast-milk substitutes } & Lack of advertisements at hospitals & 112 & 60.2 \\
\hline & Lack of total advertisement of infant formulas & 74 & 39.8 \\
\hline \multirow{2}{*}{$\begin{array}{l}\text { Place work, is there information available on the International Code } \\
\text { for infant/young child nutrition counselling }\end{array}$} & Yes & 171 & 91.9 \\
\hline & No & 15 & 8.1 \\
\hline \multirow{2}{*}{$\begin{array}{l}\text { ward, all staff follow a guideline or protocol for infant and young } \\
\text { child nutrition counselling }\end{array}$} & Yes & 135 & 72.6 \\
\hline & Not sure & 51 & 27.4 \\
\hline \multirow[t]{2}{*}{ Patient education is a core nursing function on your ward } & Yes & 176 & 94.6 \\
\hline & No & 10 & 5.4 \\
\hline \multirow{5}{*}{$\begin{array}{l}\text { Stakeholders should be targeted with the information contained in } \\
\text { the code }\end{array}$} & Mothers & 2 & 1.1 \\
\hline & Nurses & 15 & 8.1 \\
\hline & Clinicians & 7 & 3.8 \\
\hline & Doctors & 41 & 22.0 \\
\hline & All above & 121 & 65.1 \\
\hline \multirow[t]{2}{*}{ Knowledge of the IC essential and useful when counselling mothers } & Yes & 159 & 85.5 \\
\hline & No & 27 & 14.5 \\
\hline \multirow[t]{3}{*}{$\begin{array}{l}\text { If familiar with the content of the Code, in your opinion, is a nurse's } \\
\text { knowledge of the Code relevant in }\end{array}$} & $\begin{array}{l}\text { Counselling mothers on appropriate infant } \\
\text { feeding choice }\end{array}$ & 141 & 75.8 \\
\hline & $\begin{array}{l}\text { marketing of formula, feeding bottles, teats } \\
\text { and bottles by manufacturers }\end{array}$ & 40 & 21.5 \\
\hline & Nutrition and content of the formula & 5 & 2.7 \\
\hline
\end{tabular}




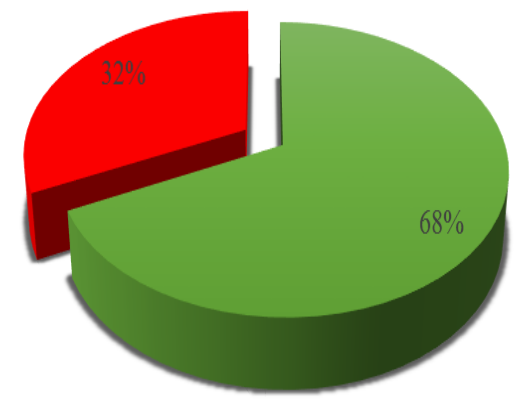

-High - Low

Figure 1 Distribution of Nurses by Level of Knowledge

Table 2 presents the responses on the nurses knowledge of the BMS Act in relation to its contents. It was established that majority were aware of IC of advertising and marketing of BMS and $44.6 \%$ indicated they learnt on BMS at their place of work while 76[40.9\%] indicated through continuing education programs while employed at my expense. Probing on the BMS Act contents on International Code Marketing Breast-milk substitutes, 112[60.2\%] cited Lack of advertisements at hospitals compared to $74[39.8 \%]$ argued Lack of total advertisement of infant formulas and this indicated they knew the BMS Act contents. It was established that there was information available on the International Code for infant/young child nutrition counselling at the study sites and majority [135,72.6\%] of the nurses at the wards followed a guideline or protocol for infant and young child nutrition counselling. The study further established that Patient education was a core nursing function on the ward as indicated by 176[94.6\%] of the respondents and the key stakeholders should be targeted with the information contained in the code the study established all those worked in the hospital sectors. Majority $[159,85.5 \%]$ of the nurses asserted that the knowledge of the IC essential and useful when counselling mothers on the superiority of breast-feeding and their opinion of the code indicated that Counselling mothers on appropriate infant feeding choice
[141,75.8\%] and $21.5 \%$ cited marketing of formula, feeding bottles, teats and bottles by manufacturers and this indicated that they had good knowledge on BMS.

Respondents in Table 2 who had 4 or more correct responses were classified as having high knowledge. Figure 1 shows that $68 \%$ of the respondents had high knowledge.

\section{Predictors of Nurses' Knowledge on BMS}

There was a significant relationship $(p=0.014)$ between the level of education and nurses knowledge on BMS. More educated nurses (bachelors and postgraduate degrees) had higher knowledge than their counterparts did.

Table 3 Predictors of Nurses' Knowledge on BMS

\begin{tabular}{|l|l|l|l|}
\hline Variable & $\mathbf{x}^{\mathbf{2}}$ & $\mathbf{d f}$ & $\mathbf{p}$ \\
\hline Institution & 0.164 & 3 & 0.983 \\
\hline Gender & 2.107 & 3 & 0.550 \\
\hline Age & 4.179 & 2 & 0.124 \\
\hline Level of education & 10.558 & 3 & 0.014 \\
\hline Working experience & 4.755 & 3 & 0.191 \\
\hline
\end{tabular}

\section{DISCUSSION}

The study sought to determine nurses' knowledge on the recommendations of the BMS Act in Mbagathi and Pumwani Hospitals, Nairobi County. The study found that majority $(68 \%)$ of the respondents had high knowledge. High knowledge of BMS recommendations was frequently found among highly educated nurses. This finding is in agreement with ${ }^{[10]}$ who found that overall breastfeeding knowledge and practices of registered nurses' was good. ${ }^{[1]}$ found that the scope of improvement regarding knowledge of breastfeeding in both doctors and nurses. ${ }^{[12]}$ also found that nursing students' level of breastfeeding knowledge was very high, and higher than that among students from other faculties. However, the finding is in disagreement with ${ }^{[13]}$ who found inconsistencies between the health-care provider's perceived support and behaviors, lack of knowledge, and significant lack of skill in the assessment and management of breastfeeding couples. 


\section{CONCLUSION}

Nurse's knowledge on the recommendations of the BMS Act is generally high. Nurses with bachelors and postgraduate degree were more likely to have high knowledge than those with certificates and diplomas in nursing. Diploma curriculum therefore needs to be bolstered to include current recommendations of breastfeeding in line with the BMS Act. County governments also need to provide continuous training on new recommendations regarding breastfeeding.

\section{Acknowledgement: None}

\section{Conflict of Interest: None}

\section{Source of Funding: None}

\section{Ethical Approval: Approved}

\section{REFERENCES}

1. World Health Organization. (2014). Global nutrition targets 2025: breastfeeding policy brief (No. WHO/NMH/NHD/14.7). World Health Organization.

2. Fomon, S.J. (2003). Protein requirements of term infants. In: Energy and Protein Needs During Infancy, S.J. Fomon, W.C. Heird, Eds., pp.55-68. Academic Press, Olrlando, Florida

3. UNICEF, (2013). The State of the World's Children 2013.

4. Kimani-Murage, E. W., Madise, N. J., Fotso, J. C., Kyobutungi, C., Mutua, M. K., Gitau, T. M., \& Yatich, N. (2011). Patterns and determinants of breastfeeding and complementary feeding practices in urban informal settlements, Nairobi Kenya. BMC public health, 11(1), 1-11.

5. World Health Organization. (1981). International code of marketing of breast-milk substitutes. World Health Organization.

6. Liu, A., Dai, Y., Xie, X., \& Chen, L. (2014). Implementation of international code of marketing breast-milk substitutes in China. Breastfeeding Medicine, 9(9), 467472.

7. World Health Organization. (2013). Country implementation of the international code of marketing of breast-milk substitutes: status report 2011.

8. Michaud- Létourneau, I., Gayard, M., \& Pelletier, D. L. (2019). Translating the international code of marketing of breast- milk substitutes into national measures in nine countries. Maternal \& child nutrition, 15, e12730.

9. Yamane, Y., \& Pázsit, I. (1998). Heuristic derivation of Rossi-alpha formula with delayed neutrons and correlated source. Annals of Nuclear Energy, 25(17), 1373-1382.

10. Alakaam, A., Lemacks, J., Yadrick, K., Connell, C., Choi, H. W., \& Newman, R. G. (2018). Maternity Nurses' Knowledge and Practice of Breastfeeding in Mississippi. MCN: The American Journal of Maternal/Child Nursing, 43(4), 225-230.

11. Shaw, S. C., \& Devgan, A. (2018). Knowledge of breastfeeding practices in doctors and nurses: A questionnaire-based survey. Medical journal, Armed Forces India, 74(3), 217-219. https://doi.org/10.1016/j.mjafi.2016.11.015

12. Natan, M. B., Haikin, T., \& Wiesel, R. (2018). Breastfeeding knowledge, attitudes, intentions, and perception of support from educational institutions among nursing students and students from other faculties: a descriptive cross-sectional study. Nurse education today, 68, 66-70.

13. Radzyminski, S., \& Callister, L. C. (2015). Health Professionals' Attitudes and Beliefs About Breastfeeding. The Journal of perinatal education, 24(2), 102-109. https://doi.org/10.1891/1058-1243.24.2.102

How to cite this article: Clement N, Beatrice G, Rose J. Assessment of knowledge of Kenya's breast milk substitutes act (2012) among nurses in Mbagathi and Pumwani Hospital, Kenya. Gal Int J Health Sci Res. 2021; 6(2): 48-53. DOI: https://doi.org/10.52403/gijhsr.20210407 